\title{
BÓG JEST OBECNY W ŚWIECIE, KIERUJE NIM I OSĄDZA GO Opatrzność Boża w dziele Salwiana z Marsylii De gubernatione Dei
}

Salwian, autor interesującego nas tutaj dzieła, urodził się w Trewirze albo Kolonii pomiędzy 390 a 400 rokiem. Pochodził z rodziny dość zamożnej, nie możemy jednak stwierdzić na pewno, czy była to rodzina chrześcijańska. W młodości otrzymał dobre wykształcenie prawnicze i retoryczne. Ożenił się z niechrześcijanką o imieniu Palladia, która pod jego wpływem przyjęła chrześcijaństwo. Z ich związku urodziła się córka Auspiciola. Po urodzeniu córki oboje małżonkowie z motywów chrześcijańsko-ascetycznych rozpoczęli życie we wstrzemięźliwości, co doprowadziło do długoletniego poróżnienia z teściami, o czym wiemy na podstawie jednego z listów Salwiana. Około 426 r. rozpoczął Salwian życie mnisze we wspólnocie w Lerynie. W tym okresie przyjaźnił się z założycielem osiedla mnichów Honoratem i późniejszym biskupem Eucheriuszem zostając wychowawcą dwóch synów tego ostatniego. Od 429 r. Salwian działał jako kapłan w Marsylii albo w Lerynie. Nie wiemy jednak, kiedy i gdzie otrzymał święcenia kapłańskie. Nie wiemy także nic o jego duszpasterskiej działalności. Umarł najprawdopodobniej pomiędzy 470 a 480 rokiem.

Dzieło Salwiana De gubernatione Dei należy czytać przede wszystkim w kontekście historycznym, czyli czasu jego życia i kościelnej działalności: był to $\mathrm{V}$ wiek, w którym pod wpływem rozkładu wewnętrznego państwa oraz wędrówek ludów następuje upadek Cesarstwa Rzymskiego - 24 sierpnia 410 r. król Wizygotów Alaryk, zdobywa Rzym. Miało to po raz pierwszy miejsce w ponad tysiącletniej historii państwa, a dla Rzymian wówczas dosłownie „runął świat”. Mieszkańcy Wiecznego Miasta, zwłaszcza ci, którzy kultywowali jeszcze starą rzymską religię, zaczęli zarzucać chrześcijanom, że to ich Bóg przyczynił się do tego, że stare bóstwa odmówiły Rzymowi ochrony i opieki: za ten „koniec świata” obwiniano więc chrześcijaństwo. To ono na skutek wyparcia starych bóstw przyczyniło się do upadku Cesarstwa. Także chrześcijanie stawiali pytanie, dlaczego Bóg nie obronił ich przed inwazją?

Dzieło Salwiana można jednak czytać także w kontekście czasów nam współczesnych, bo stawia ono problemy zawsze aktualne. Problem, jaki w ówczesnym kontekście wydarzeń historycznych nurtował wszystkich ludzi, 
w tym chrześcijan, dotyczył w istocie kwestii opatrzności Boga. Czy Bóg interesuje się światem, czy ma wpływ na dziejowy proces, czy troszczy się i ochrania ludzi przed grożącym złem? Na te właśnie pytania Salwian próbuje udzielić odpowiedzi w swoim dziele. Tę odpowiedź można streścić w następujących słowach: Bóg jest obecny w świecie, kieruje nim i osądza go - ta myśl dominuje w całym dziele.

Pierwszorzędną sprawą jest kwestia obecności Boga w świecie i troska o niego. Gdzie jest Bóg? Takie pytanie stawiają często ludzie, których dotyka choroba, cierpienie, gwałtowna śmierć młodego, bliskiego im człowieka. Wątpią w istnienie Boga czy Jego zainteresowanie tym światem i sprawami ludzkimi. Dlaczego człowiek dobry i religijny doznaje wielu cierpień, jego życie jest pasmem klęsk, bolesnych doświadczeń, a na tym tle ludziom złym i niegodziwym żyje się aż nadto dobrze, na krzywdzie ludzkiej zbijają fortuny w zdrowiu i pomyślności? Jaka jest wówczas logika boskich rządów nad światem, o ile w ogóle Bóg tym światem się interesuje i ma jakiś wpływ na jego dzieje, na życie i sprawy przeciętnego człowieka? Takie pytania i problemy stawia dziś często człowiek. Tego rodzaju pytania stawiali także ludzie w czasach życia Salwiana z Marsylii. Zbiera on je i przedstawia w różnych miejscach swojego dzieła. Czytając je możemy poddać się wrażeniu ich ponadczasowej aktualności.

Jaka jest odpowiedź Salwiana na powyższe pytania? Nie sposób do końca przewidzieć logiki boskiego działania; w całej swej głębi działanie to jest tajemnicą. Człowiek nie zawsze jest w stanie znaleźć odpowiedź na pytanie, dlaczego...? Boża obecność, działanie i sąd są jednak w świecie faktem. Stoi za tym autorytet słowa Bożego zawarty na kartach Starego i Nowego Testamentu. Słowo Boże pozwala zrozumieć, że to działanie ma zawsze sens i zawsze jest sprawiedliwe, bo nic, co dzieje się z woli Bożej, nie może uchodzić za coś innego ${ }^{1}$. Salwian cytuje bardzo wiele tekstów biblijnych, w świetle których sam Bóg daje świadectwo o rządach nad światem. Czyni to między innymi w następujących słowach:

„,[...] Pismo święte mówi, że wszystkim każdego dnia kieruje wola Boża i nieustannie Bóg wszystkim rządzi. «On sam bowiem miłuje planowość i porządek» (Syr 39, 10). «Nie ma bowiem oprócz Ciebie boga, co ma pieczę nad wszystkim » (Mdr 12,13). «Tyś sprawiedliwy i rządzisz wszystkim sprawiedliwie [...] i rządzisz nami z wielką oględnością» (Mdr 12,15 i 18). Znajdujesz tu Boga, który zawsze wydaje

${ }^{1}$ Por. Salvianus Massiliensis, De gubernatione Dei III 1, 2-3, ed. G. Lagarrigue, SCh 220, 186: „Zapewne mógłbym racjonalnie i stanowczo odpowiedzieć: nie wiem, nie znam bowiem tajemniczego zamysłu Boga. Za cały dowód w tej sprawie wystarczą mi bowiem wypowiedzi boskiej wyroczni. Jeśli chcesz wiedzieć, czego należy się trzymać, to masz Pismo Święte. Istnieje pełne uzasadnienie, by przyjąć to, co w nim przeczytasz. Nie pytaj mnie jednak, dlaczego Bóg postępuje w taki sposób, jak mówimy? Jestem człowiekiem, nie rozumiem tajemnic Bożych. Nie mam odwagi ich dociekać i dlatego także doznaję obawy, ponieważ rodzajem zuchwałej bezbożności jest chcieć wiedzieć więcej niż wolno". 
dyspozycje, który rządzi nieustannie, chociaż w tym miejscu Pisma Świętego nie tyle ukazano święte rządy, co ludzką godność. W tym bowiem, co mówi, okazuje się nie tyle siła boskich rządów, co wielki szacunek dla człowieka i wzgląd na jego wielką godność"2.

Na twórczą obecność Boga w świecie wskazuje nie tylko Biblia i wyprowadzająca z niej wnioski myśl chrześcijańska. Obecność i działanie Boże w świecie człowiek może rozpoznać i doświadczyć tylko zdolnościami swojego rozumu. Przykładem są starożytni filozofowie, dla których Biblia nie tworzyła świata ich wierzeń. Salwian odwołuje się między innymi do myśli stoickiej, która porównuje Boga do sternika:

„Stoicy poświadczają, że na sposób sternika mieszka on w tych, którymi kieruje. Czyż można w sposób bardziej słuszny i sumienny przedstawić obecność i troskę Boga o świat [...]? Bez wątpienia rozumieją oni przez to, że jak sternik żeglujący po morzu nigdy nie wypuszcza steru z rąk, tak troska Boga o świat nie słabnie ani przez chwilę. Gdy sternik sprawdza powiew wiatru, unika podwodnych skał, bada gwiazdy, czyż nie jest całkowicie oddany zarówno ciałem jak i duszą swojemu zadaniu? Tak samo nasz Bóg nie pozbawia wszechświata dobrodziejstw, jakie wynikają z jego dostojnego spojrzenia; nie można Mu odmówić ani rządów, jakie wynikają z jego opatrzności, ani pobłażliwości, jaka jest wyrazem Jego życzliwej miłości”3.

Sama obserwacja świata zmusza człowieka do uznania obecności Boga w świecie i rządów nad nim. Świat jest najpiękniejszym dziełem Boga. Człowiek tylko na podstawie racji rozumowych jest w stanie wnioskować o harmonii wszechświata oraz głębi i logice występujących w świecie prawideł. Kto je ustanowił? Kto czuwa nad ich funkcjonowaniem? Rozum ludzki, niekoniecznie wzbogacony o objawioną wiarę w osobowego Boga, zwraca się w tym przypadku w kierunku najwyższej boskiej Istoty, która nie tylko świat stworzyła, ale zarządza nim mocą ustanowionych przez siebie praw. Wszelkie zarządzanie człowieka partycypuje tylko w rządach Boga ${ }^{4}$.

\section{Tamże II 2, 8, SCh 220, 164.}

3 Tamże I 1, 3, SCh 220, 102.

${ }^{4}$ Por. tamże I 4, 19-20, SCh 220, 118-120: ,Czy jest jakiś człowiek pozbawiony rozumu do tego stopnia, że obca byłaby mu prawda, o której mówimy, który nie poznałby, a także nie dostrzegał najpiękniejszego dzieła, jakim jest świat, że to, co stanowi nieoszacowaną wspaniałość tego, co na niebie i tego, co na ziemi, kierowane jest przez Tego, co je stworzył, że Ten, który te wszystkie elementy uczynił, zarządza nimi; że Ten, który z mocy i majestatu wszystkie te rzeczy ustanowił, kieruje nimi swoją opatrznością i myślą, tak iż nawet w sprawach, którymi zarządzają ludzie, nic nie może zaistnieć bez jego myśli, i że wszystko zawdzięcza swoje istnienie dzięki jego opatrzności, podobnie jak ciało utrzymuje się przy życiu dzięki duszy. Oto dlaczego w tym świecie nie tylko cesarstwa i prowincje, sprawy cywilne i wojskowe, lecz także ważne służby, sprawy rodzinne, w końcu samo bydło, wręcz najmniejsze gatunki zwierząt domowych, które są pod kontrolą rozporządzeń i kalkulacji ludzkich, pod czyjąś ręką i kierownictwem: wszystko to bez wątpienia dzieje się na skutek woli i osądu Boga Najwyższego, czyli cały rodzaj ludzki zarządzając częścią spraw ma udział we władzy Boga, który zarządza całością wszechświata”. 


\section{Według Salwiana za opatrznością Bożą nad światem przemawiają również} argumenty typu religijnego. Kto twierdziłby, że Bóg po stworzeniu świata przestał interesować się swoim dziełem, podważałby podstawy i sens jakiegokolwiek kultu religijnego. Każdy bowiem człowiek religijny prosi Boga w modlitwie i składa mu ofiary, nie tylko o dobra przyszłe po śmierci, ale i o pomyślność podczas życia na tym świecie, o pokój dla świata i spokojną realizację swojego powołania ${ }^{5}$.

Jak można wyrazić sposób obecności Boga w świecie? Salwian odwołuje się najpierw do antropomorfizmów, świata zmysłów człowieka. Zmysły człowieka stanowią o jego kontakcie ze światem. Szczególnie oczy i uszy pozwalają poznać świat i jego problemy, mieć wgląd w sprawy świata i usłyszeć o jego sprawach, dobrych i złych, okazać posłuch dla problemów i trosk człowieka. Te antropomorfizmy, których Pismo Święte zna wiele, pozwalają dobrze oddać sposób obecności Boga w świecie ${ }^{6}$. Bóg dostrzega wszelkie przejawy ludzkiej działalności. Szczególny wzgląd ma na czynione dobro. Jest także zawsze gotowy, by okazać posłuch dla wszystkich ludzkich spraw i skarg. Czyż nie stanowi on tutaj idealnego wzorca także dla ludzkiego działania? ${ }^{7}$.

${ }^{5}$ Por. tamże I 5, 12, SCh 220, 120: „Powiadasz więc, że Bóg odsuwa daleko od siebie troskę o śmiertelników: jaki więc mamy powód oddawać cześć Bogu? Jaki mamy motyw w oddawaniu czci Chrystusowi? Jakiej nadziei mamy oczekiwać? Jeśli Bóg w tym przemijającym świecie zaniedbuje rodzaj ludzki, dlaczego każdego dnia wyciągamy nasze ręce w stronę nieba? Dlaczego częstymi modlitwami błagamy miłosierdzie Boga? Dlaczego biegniemy do kościołów? Dlaczego przed ołtarzami wznosimy modły błagalne? Nie mamy w rzeczywistości żadnego powodu, aby się modlić, jeśli nie mamy żadnej nadziei na uzyskanie zadość naszym prośbom. Widzisz więc głupotę i bezsens takiego przekonania, które jeśliby przyjąć, nie pozostawia juz żadnego miejsca na religię".

6 Por. tamże II 1, 3, SCh 220, 160: „Lecz, abyś lepiej zrozumiał, posłuchaj, co stwierdza ten sam Duch Święty w innym miejscu Pisma: «Oto oczy Pana nad tymi, którzy się Go boją, aby ocalić ich życie od śmierci i żywić ich w czasie głodu» (Ps 33, 18-19). Oto dlaczego mówi się, że Bóg spogląda na sprawiedliwych, aby ich zachować i aby ich chronić. Przychylne spojrzenie Boga jest darem zmiłowania, które chroni człowieka. Albowiem w innym miejscu mówi ten sam Duch: «Oczy Pana zwrócone są ku sprawiedliwym, a Jego uszy na ich wołanie» (Ps 34, 16). Spójrz jak w dobrotliwy sposób Pismo Święte ukazuje działanie Boga względem nich. W tym, że mówi ono, iż oczy Boga zwrócone są na sprawiedliwych, okazuje zapewne przychylność patrzącego, w tym zaś, że uszy jego są zawsze gotowe do wysłuchania ich próśb, wyraża się obfitość laski słuchającego. Jednakże trzeba powiedzieć, że w stwierdzeniu, iż uszy Boga są zawsze otwarte na wołanie sprawiedliwych, nie wskazuje wyłącznie na to, że On słucha, ale jednocześnie słowa te wskazują na uległość Boga".

${ }^{7}$ Por. tamze II 1, 4, SCh 220, 160-162: „W jaki sposób w rzeczywistości uszy Boga są otwarte na błagania sprawiedliwych? W jakiż by inny, jak nie taki, aby zawsze słuchać, aby zawsze wysłuchać, nie inaczej, aby ochoczo zgodzić się z usłyszaną prośbą, nie inaczej, aby przychylić się do usłyszanej prośby. W rzeczywistości uszy naszego Pana są zawsze otwarte na wysłuchanie modlitw ludzi świętych, zawsze są one czujne. Gdybyśmy chcieli słuchać Boga z taką gorliwością, z jaką czytamy, że Bóg nas wysłuchuje, to wszyscy bylibyśmy szczęśliwymi ludźmi. Lecz może powiesz, że fakt, iż Bóg według Pisma Świętego spogląda na sprawiedliwych, jest zbyt wątły dla sprawy, której bronię, ponieważ wzgląd bóstwa tylko na część ludzi, dowodzi tylko specjalnej jego życzliwości wobec tej właśnie części ludzi sprawiedliwych". 
Dla Salwiana dobrą ilustracją obecności Boga w świecie jest także powołanie człowieka przez Boga i proces jego realizacji w życiu konkretnego człowieka, jego interwencja w życiu konkretnych ludzi, jego proces kierowania człowiekiem i jego sprawami oraz osądzania toku ludzkich spraw. Stanowi o obecności Boga w życiu konkretnego człowieka, czyli towarzyszenie człowiekowi na drogach realizacji jego powołania w chwilach radości, a także próby. Wielu powołanych na przestrzeni dziejów mogłoby złożyć w tym względzie niejedno świadectwo, które w wielu miejscach byłoby odzwierciedleniem dziejów powołania Abrahama oraz sprawczo-kierowniczej obecności Boga w procesie jego realizacji. Salwian następująco ukazuje obecność i działanie Boga w życiu Abrahama:

„Gdy po potopie Bóg pobłogosławił rodzajowi ludzkiemu, a samo to błogosławieństwo spowodowało narodziny ogromnej liczby ludzi, Pan zwraca się z nieba do Abrahama z poleceniem, aby opuścił swoją ziemię i poszukał obcej. Abraham zostaje powołany i temu powołaniu okazuje posłuszeństwo. Bóg go prowadzi i wskazuje mu miejsce zamieszkania. Z człowieka ubogiego staje się on zamożnym. Dotychczas nieznany człowiek uzyskuje wielkie znaczenie. Wędrówka do obcej krainy czyni z niego znakomitego męża. Aby się jednak nie wydawało, że dobra, których udzielił mu Bóg, były niezasłuzonymi darami, po radościach z dobrobytu doświadcza on [Abraham] przeciwności losu. Następują więc trudności, niebezpieczeństwa i strach; trud wędrówki, dokuczliwość wygnania, doznanie zniewagi, utrata małżonki. Bóg polecił, aby zabił Mu w ofierze swojego syna. Ojciec ofiarowuje go. I trzeba powiedzieć, że składa tę ofiarę z całego serca. Ponowne wygnania, znowu strach, nienawiść ze strony Filistynów, rabunek, którego dopuścił się Abimelek. Doznaje więc z pewnością licznych niepowodzeń, jednak w równej mierze także pociechy. Chociaż bowiem doznaje wielu udręk, to jednak wszystko to zostaje mu wynagrodzone" ${ }^{\text {. }}$.

Z tych przejawów obecności Boga w życiu Abrahama Salwian wyciąga następujący wniosek:

„Czy w tych wszystkich faktach, które przywołaliśmy, Bóg nie jest jednocześnie tym, który spogląda, powołuje, prowadzi, troszczy się, obiecuje, chroni, nagradza, wystawia na próbę, umacnia, dokonuje pomsty, sądzi? On patrzy uważnie, ponieważ sam wybiera spośród wszystkich ludzi tego, który wydaje mu się lepszym od innych. On wzywa, kiedy powołuje; prowadzi, kiedy wiedzie go do nieznanych miejsc; jest pełen troskliwości, kiedy składa mu wizytę pod dębem; obiecuje, kiedy zapewnia go o swoich zamiarach na przyszłość; chroni go, kiedy otacza opieką pośród barbarzyńskich narodów; wynagradza, gdy czyni go bogatym; poddaje go próbie, ponieważ niepokoi przeciwnościami; umacnia go, gdyż czyni go potężniejszym od wszystkich; dokonuje pomsty, ponieważ karze jego przeciwników, sądzi, ponieważ jego pomsta wynika z sądu".

\footnotetext{
8 Tamże I 8, 35, SCh 220, 132-134.

9 Tamże I 8, 36, SCh 220, 134.
} 
Na sposób obecności i działania Boga w świecie wskazuje, według kapłana z Marsylii, także sama Jego istota. Bóg jest Miłością. Miłość, do której zdolny jest człowiek, partycypuje w miłości Boga. W ojcowskiej miłości Boga w sposób najbardziej widoczny wyraża się jego troska o świat i człowieka. Jest to miłość zbawcza:

„Bóg zatem, który wszczepił to uczucie przywiązania dla własnego dzieła nawet najmniejszym żyjącym istotom, siebie samego jedynie miałby pozbawić miłości do własnych stworzeń, skoro wszelka nasza miłość do rzeczy dobrych pochodzi z Jego dobrotliwej miłości? [...]. A przecież cały świat i cały rodzaj ludzki jest dziełem swego Stwórcy. Toteż dając nam miłość do naszych dzieł, chciał, abyśmy z uczucia tego nabrali wyobrażenia, jaką miłością darzy On sam swoje dzieła [...]. I jak o czym pisze Pismo Święte - sam Bóg chciał, aby wszelkie ojcostwo na niebie i na ziemi od Niego brało swą nazwę, tak chciał również, abyśmy w Nim poznali miłość ojcowską. Cóż mówię: ojcowską? Raczej więcej, niż ojcowską. Potwierdzają to zapewne słowa Zbawiciela, który powiada w Ewangelii: «Albowiem tak Bóg umiłował świat, że swojego Syna jedynego oddał za życie świata» $(\mathrm{J} 3,16){ }^{» 10}$.

W myśli Salwiana ważnym argumentem za obecnością Boga i jego troską o świat i sprawy ludzkie, oraz rządów nad tym światem jest także boski sąd. „Przyjdzie sądzić żywych i umarłych”. W tych słowach wyraża się nasza wiara w ponowne przyjście Chrystusa na ziemię i jego sąd nad światem, gdy dobiegnie on swojego kresu. Przyszły sąd Boga nad światem nie przeczy jednak - zdaniem Salwiana - obecnemu sądowi Boga, jaki nieustannie związany jest z jego rządami nad nim, we wszystkich okresach jego dziejów ${ }^{11}$. Salwian podaje w swoim dziele różne przykłady takiego aktualnego sądu Boga, o których mówi Biblia. Interpretuje on między innymi sąd Boga nad mieszkańcami Sodomy i Gomory: wraz z coraz większymi grzechami mieszkańców Sodomy i Gomory wznosił się do Boga coraz większy krzyk wywołany ich grzechami. Krzyk ten przeważył szalę Bożego miłosierdzia i skłonił Boga do ukarania grzeszników po dokonaniu sądu $^{12}$. Ten ówczesny sąd jest obrazem przyszłego sądu ${ }^{13}$.

Aktualny sąd Boga, zdaniem kapłana z Marsylii, miał także miejsce w czasach jego życia, gdy oblicze Pana zwróciło się przeciw źle czyniącym ${ }^{14}$.

10 Tamże IV 9, 44-45, SCh 220, 268.

11 Por. tamże I 4, 18, SCh 220, 118: „Jeśli chodzi o nas, to twierdzenie, że Chrystus będzie sądził rodzaj ludzki, nie przeczy przekonaniu, że obecnie w sposób racjonalny Bóg wszystkim kieruje, a także zarządza wszystkimi sprawami. Twierdzimy, że w fakcie przyszłego sądu zawiera się pouczenie, że Bóg dokonuje nieustannie sądu nad tym światem”.

12 Por. tamże I 8, 37-38.

13 Por. tamże I 8, 39

14 Por. tamże IV 8, 34, SCh 220, 260: „Czyż jest zatem miejsce na skargę? Aczkolwiek doznajemy przykrych przeciwności, to jednak cierpimy w mniejszym stopniu niż na to zasługujemy. Dlaczego skarżymy się, że Bóg obchodzi się z nami surowo? My bowiem względem Boga jesteśmy o wiele bardziej okrutni. Oburzamy go zapewne naszym rozwiązłym trybem życia i wbrew Jego woli skłaniamy Go do tego, by nas karał. Chociaż bowiem duchowy majestat Boga z natury 
W zagładzie, zniszczeniach i różnego rodzaju nieszczęściach, jakie niosły za sobą wędrówki ludów, wyraża się surowość Boga, który osądza i karci chrześcijan za wyrządzone przez nich zło, które Go obraża. Każdy grzesznik sam na siebie ściąga sąd i karę Boga ${ }^{15}$. Jeśli nie nawróci się, przyszły sąd będzie stanowił o przyszłej karze wiecznej. Taka jest ostateczna wymowa dzieła Salwiana De gubernatione Dei, za którą idzie wezwanie do nawrócenia.

W konkluzji należy stwierdzić, że jakkolwiek Salwian z Marsylii w De gubernatione Dei traktuje o obecności Boga w świecie i rządach nad nim w kontekście różnych faktów i wydarzeń także w jego czasach, to jednak nie możemy traktować tego pisma jedynie jako prostego komentarza do aktualnych wydarzeń. De gubernatione Dei jest traktatem, w którym zawiera się określona teologiczna teza na temat opatrzności Bożej. Salwian opatrzności Boga nie traktuje jednak ogólnie. Jej konkretny przejaw dostrzega w rządach Boga nad światem i w obecnym sądzie nad nim, przy czym jednego nie można oddzielić od drugiego: „Tak więc, jeśli jest szaleństwem i bezbożnością uważać, że ojcowska dobroć Boga odwraca wzrok od ludzkich spraw, to On nimi nie gardzi. Otóż jeśli On nimi nie pogardza, to nimi kieruje, a jeśli rządzi, to tym samym to, czym zarządza, podlega Jego sądowi, ponieważ nie może istnieć najwyższa władza, która nie wykonywałaby ustawicznie sądu" 16 .

GOTT IST ANWESEND IN DER WELT, LEITET UND BEURTEILT SIE. DIE GÖTTLICHE VORSEHUNG NACH DEM WERK SALWIANUS VON MARSEILLE DE GUBERNATIONE DEI

\section{(Zusammenfassung)}

Der Artikel stellt die Lehre von der Gottes Vorsehung vor, welche in $5 \mathrm{Jh}$. Salvianus, der gallische Presbyter, im Werk De gubernatione Dei bildet. Das Salvianus Unterrichten stellt der Urheber dieses Artikels nicht nur im Kontext der Zeitläufe vor, in deren lebte Salvianus (der Fall des römischen Kaiserreiches und im

nie doznaje uczucia gniewu, to jednak w nas jest tak wielka złość grzechów, że zmuszamy tym Boga, by na nas się gniewał. Powiedziałbym, że w ten sposób zadajemy gwałt Bożej miłości i podnosimy niejako rękę na Jego miłosierdzie. Chociaż bowiem z łaskawości swojej chciałby nam ustawicznie pobłażać, to jednak grzechy nasze zmuszają Go do karania występków, których się dopuszczamy".

15 Por. tamże IV 8, 36, SCh 220, 260-262: ,,[...] gdy popełniamy to, czego Bóg zakazuje nam czynić, depczemy rozporządzenia Zakazującego. Dlatego niegodziwie oskarżamy Boga o srogość, gdy dotykają nas różnego rodzaju nieszczęścia. Zapewne musimy tutaj winić samych siebie. Albowiem gdy dopuszczamy się tego, za co cierpimy, to sami jesteśmy sprawcami naszych cierpień. Dlaczego więc skarżymy się na dolegliwość kar? Każdy z nas wymierza karę samemu sobie".

16 Tamże I 5, 26, SCh 220, 124. 
Zusammenhang damit Anklagen, dass das Christen Ursache dieses Falles sind), sondern auch im Kontext der Zeitläufe uns gleichzeitig. Immer sind aktuelle Fragen, welche der Mensch stellt: Gott interessiert sich für die Welt? Hat Er den Einfluss auf den geschichtlichen Prozess? Gott sorgt und beschützt Menschen vor dem drohenden Übel? Auf diese Fragen versucht Salvianus Antworten in seinem Werk zu erteilen. Gott ist anwesend in der Welt, leitet und beurteilt sie. Dieser Gedanke geht durch das ganze Werk vorbei. 